Andrzej Harasimiuk, Magdalena Cyrczak

\title{
SOIL-PLANT RELATIONS ON SANDY GRASSLAND IN THE MIDDLE VISTULA RIVER VALLEY
}

\begin{abstract}
The paper is on environmental condition of sandy grassland on alluvial deposits. The soil and phytosociological study ware conducted south of Warsaw in middle Vistula river valley. Listing of vascular plants and shallow soil sampling were made in order to answer the question of plant and soil relationship. Standard chemical determination directed on trophism were done in plant and soil material. The spatial distribution of chemical parameters of plants and soils is related to local microrelief and distance of Vistula river. The plants dominating the study prefer less fertile habitats. The soil is being enriched by water from the Vistula river. High carbon content is correlated with the presence of the Salix arenaria. The greater the share of vegetation not belonging to the grass family, the greater the carbon content. Potassium and phosphorus looks like to be the less plant-dependent elements. Its documents an initial stage of development of the Vistula river valley environment.
\end{abstract}

Key words: sandy grassland, fluvisol, poor trophism habitats.

\section{INTRODUCTION}

The article takes up the problem of habitat conditions necessary for the presence of grassland on sandy soil in river valley locations. It is concentrated on soil-plant relations and the indications of their mutual effect upon each other. The studies were conducted in an area of poor trophism, where the soil is still forming and where differences are easy to notice with regard to the physicochemical parameters of the soil and the composition of plant species that populating these regions, the sandy soil grassland plants are able to affect the regions enough to cause clearly visible changes in the physicochemical parameters of the soil. This is possible due to the low level of trophism of the habitat. In the case of fertile habitats, the changes in the mineral substrate following the introduction of plants are much more weakly expressed due to the habitats' high nutrient content (a huge buffer against the effects caused by vegetation).

As plant communities, areas of sandy grassland are usually poor with regards to species diversity relative to other plant communities. They also frequently are the beginning or transitional stages in the succession of plant communities. Within the dynamic groups of communities, they are often the socalled substitute communities for various natural communities in habitats 
with sandy, or gravelly-and-sandy soil. Grasslands are often made up of incidental communities of those species that first came to occupy a given habitat and for this reason it is difficult to determine their taxonomic position (Matuszkiewicz, 1984). They undergo a certain deformation and ruderalization (e.g. resembling communities of therophytes); it is often difficult to classify them as a certain type.

The studies were aimed at answering the question regarding the influence of the sandy grassland plants on the soil environment, and at determining the factors that have an effect upon the lithological soil and plant characteristics (in relation to the water table of the Vistula River). A whole separate matter was the attempt to specify the extent of habitat variables controlling the occurrence of sandy grasslands.

\section{THE STUDY AREA}

The study area, about 2 hectares in size, is located in the middle section of the Vistula valley, on the east side of the river, south of Warsaw, right below the mouth of the tributary Świder-river. The area is not morphometrically diverse and lies $86-87$ meters above sea level, which is $1-2$ meters above the mean level of the Vistula water table. Given such morphological conditions and sandy soil, the type of microrelief present can have a significant effect, which is why special field survey measurements were conducted.

While the soil parent material is composed of sandy alluvial deposits accumulated by the Vistula, the soil of the region studied can be classified, according to Tomaszewski's (1969) system, as: grassland, alluvial mineral fluvisol with a sandy silt base. Its humus horizon is at the initial development stages and generally turns into mineral under-soil, without going through intermediate levels. The thickness of the turf horizon ranges from 14 to $27 \mathrm{~cm}$. Below the turf horizon, which spatially corresponds to the humus horizon $(\mathrm{Ah})$, lies a mineral level that has developed in fine and loose light-greycolored sand. Apart from the clearly delineated turf horizon, the entire profile has a homogeneous structure and coloring. The arrangement of the genetic levels can be symbolized as Ad-C or Ah-C.

\section{METHODS}

The studies conducted combine elements of phytosociological as well as soil studies, what makes possible the quantitative and qualitative presentation of the relations between plants and soil. The field studies were focused on two sets of issues:

- making a listing of vascular plants, describing the current state of vegetation in key areas chosen so as to represent the local diversity of the plant cover and of the topography of the terrain,

- performing shallow soil sampling (up to $1 \mathrm{~m}$ in depth), at locations in which the plant listings were made (Fig. 1). 


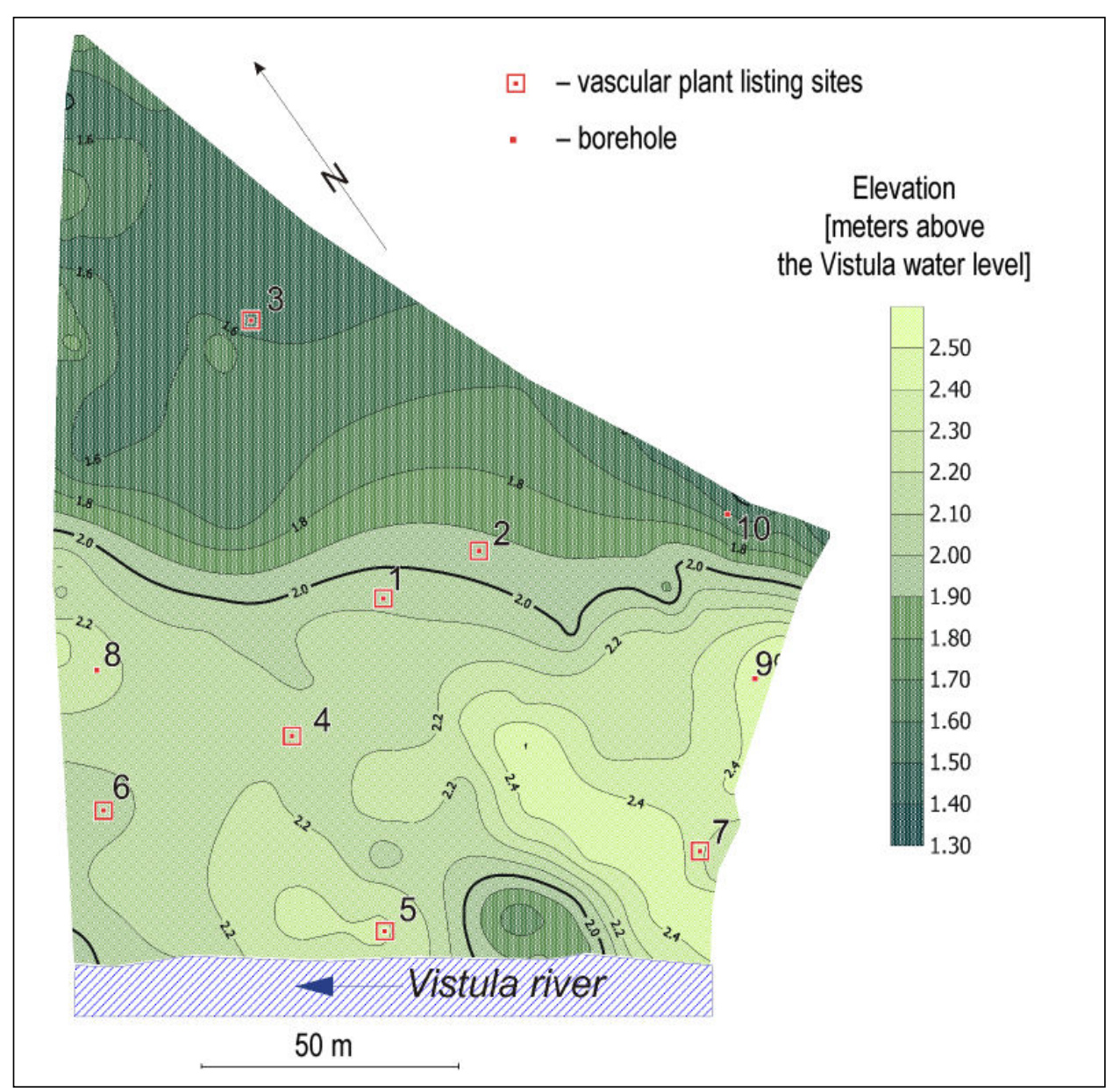

Fig. 1. Study Area.

The soil samples were taken at the humus horizon, and then at the depth of $25 \mathrm{~cm}$ (if humus horizon thickness was less than $25 \mathrm{~cm}$ ), $50 \mathrm{~cm}, 75 \mathrm{~cm}$ and $100 \mathrm{~cm}$. Plant material was collected from around the boreholes.

The samples were analyzed by the standard methods (Ostrowska et al., 1991), by making the following measurements (Tab. 1):

- soil $\mathrm{pH}$ in $\mathrm{H}_{2} \mathrm{O}$ and $\mathrm{KCl}$ - by the electrometric method,

- organic carbon content in the upper horizons of the profiles - by the Tiurin method,

- organic carbon content of the plant material - by the loss of ignition method,

- nitrogen $(\mathrm{N})$ content - by the Kjeldahl method,

- phosphorus (P) content - by the colorimetric method,

- potassium (K) content - by the flame spectrophotometry method. 
Table 1.

The N, P, K and C content of the humus (turf) horizon at all the sites in the study area

\begin{tabular}{|c|c|c|c|c|}
\hline Site number & $\mathrm{N}(\%)$ & $\mathrm{P}(\mathrm{mg} / 100 \mathrm{~g})$ & $\mathrm{K}(\mathrm{mg} / 100 \mathrm{~g})$ & $\mathrm{C}(\%)$ \\
\hline 1 & 0.094 & 480.0 & 140.0 & 1.62 \\
\hline 2 & 0.134 & 820.0 & 246.0 & 1.77 \\
\hline 3 & 0.206 & 1010.0 & 35.6 & 3.12 \\
\hline 4 & 0.155 & 800.0 & 293.0 & 2.27 \\
\hline 5 & 0.153 & 680.0 & 196.0 & 1.19 \\
\hline 6 & 0.200 & 960.0 & 211.0 & 2.41 \\
\hline 7 & 0.205 & 1080.0 & 264.5 & 2.84 \\
\hline 8 & 0.174 & 300.0 & 291.0 & 2.39 \\
\hline 9 & 0.158 & 800.0 & 234.0 & 2.62 \\
\hline 10 & 0.210 & 1200.0 & 391.0 & 2.61 \\
\hline
\end{tabular}

For comparing the nutrient content of plant and soil samples, the $\mathrm{W}_{x}$ concentration coefficient was created. It is the ratio of the content of the given element $x$ (nitrogen, phosphorus, potassium or carbon) in a sample of vegetation mass, to the content of that element within the soil (at the humus horizon).

$$
W_{x}=\frac{C_{r(x)}}{C_{A h(x)}}
$$

where:

$x$ - nitrogen, phosphorus, potassium or carbon

$C_{r(x)}$ - the content of element $x$ in the plant material,

$C_{A h(x)}$ - the content of element $x$ at the humus horizon.

An analogous procedure was used to calculate the concentration of elements determining the trophism of the soil, comparing their content at the humus horizon and in the soil parent material.

\section{RESULTS AND DISCUSSION}

Soil and habitat analysis: Soil $\mathrm{pH}$ : The soil $\mathrm{pH}$ in the area studied can be described as neutral or slightly basic. A general tendency of the soil to become more alkaline deeper in the profile was observed at all the sites, except that at almost all of the sites, slight local acidity was determined at the depth of $75 \mathrm{~cm}$. One can conclude that the soil in the area studied is alkalized by an outside agent - the polluted and organic substance-rich waters of the Vistula, for example. According to data from the Voivodship 
Inspectorate of Environmental Protection (WIOŚ) in Warsaw, in 2002 the mean water $\mathrm{pH}$ of the Vistula at the Kepa Zawadowska control site was 8.1 (minimally 7.1 - maximally 8.9$)$. The values for phosphates $(0.4 \mathrm{mg}$ $\left.\mathrm{PO}_{4} / \mathrm{dm}^{3}\right)$ and total phosphorus $\left(0.3 \mathrm{mg} \mathrm{P} / \mathrm{dm}^{3}\right)$ were similarly high.

Soil nutrient content: According to A. Musierowicz (following: Lityński, Jurkowska, 1982), in Poland the organic carbon content of alluvial horizons $0-15 \mathrm{~cm}$ thick is $0.64 \%-2.44 \%$. The results obtained fit within or exceed this range of values. It was observed that the highest values were obtained at sites at which soft-leafed vegetation not belonging to the grass family Canada goldenrod (Solidago canadensis), forest pea (Lathyrus silvestris), and lady's bedstraw (Galium verum) - was present to a significant degree. Relative to other vegetation occurring in the area studied, grasses generally have more supportive and conductive tissues than they have parenchyma, what makes them more "firm-leaved" than the three species mentioned above. Due to the breaking off of successive cellulose layers, the cells of supportive and conductive tissues usually have thickened cell walls, what impedes their decomposition in the soil (Lerch, 1976).

It was the case however that despite the difference in organic carbon content between the sites $(1.62 \%$ and $2.41 \%)$, the composition of the set of species collected at the two sites was very similar, since both the blue (sheep) fescue (Festuca ovina) and the common horsetail (Equisetum arvense) do not require high trophism as expressed in the humus content.

Nitrogen, the second parameter determining the trophism of the habitat, has a concentration level of $0.09 \%$ to $0.21 \%$ (mean of $0.17 \%$ ) in the humus horizon. The highest nitrogen content was noted at sites 3, 7 and 10 (over $0.20 \%$ at turf horizon); sites which are located at various distances from the Vistula (site 3 is the farthest away from the shore - approximately $130 \mathrm{~m}$; site 7 is about $30 \mathrm{~m}$ and site 10 about $100 \mathrm{~m}$ away from the Vistula). The lowest values for nitrogen were noted at sites 1 and 2 (under $0.15 \%$ ) - both of these sites are located in the central section of the terrain, in an area of local land elevation. High nitrogen content was observed at those sites that are the closest to the Vistula (sites 6 and 7), what may be caused by the river water's more frequent flooding and enriching of these areas. The low nitrogen content at site 5 may be attributed to its elevated location (in contrast to sites 6 and 7, which are located in depressions of the terrain). Similarly high nitrogen content is also noted at sites 3 and 10 which are located in depressions, where (at times when the water level of the Vistula is high), there is effective contact with the ground water level.

The value of the C:N ratio is determined by the amount of unhumificated compounds in the soil (the greater the amount of compounds, the higher the $\mathrm{C}: \mathrm{N}$ ratio). The $\mathrm{C}: \mathrm{N}$ ratio required by microorganisms living in the soil is about 20. If that value is exceeded, the decomposition of organic matter is impeded, and moreover, microorganisms become the undesired rivals of higher-order plants in nitrogen uptake (Musierowicz, 1960). The lower the C:N ratio, the more efficient the higher plants' utilization of nitrogen (Lityński, 
Jurkowska, 1982). In the study area, the highest value of C:N is around 17, which is near the value that is optimal for the activity of soil microorganisms.

Vascular flora analysis: Overall, 9 families were found to be present, of which the most highly represented were two families: Compositae (the sunflower family) -6 species, and Poaceae (the grass family) - 5 species. The high number of the Compositae can be explained by the fact that the members of this family are able to produce great amounts of fruit quickly what has contributed to their wide distribution (Szweykowska, Szweykowski, 1993). The Poaceae family is characterized by the high ability to adapt to life in various ecological conditions. Furthermore, anemochory (the dispersal of seeds by the wind) enables the members of this family to quickly spread to previously unvegetated areas. Three species of plants from the Papilionaceae (pea and bean) family, which may act to improve the fertility of the habitat's soil by symbiosis with the nitrogen-fixing, nodule-inducing Rhizobium bacteria, were also found to be present in the study area.

Examining the influence of $\mathrm{pH}$ upon the spread of vegetation (Zarzycki, 1984), one notices that species preferring a slightly acidic habitat dominate, what is consistent with the $\mathrm{pH}$ values obtained for the soil. Due to the wide range of requirements of the different plant species with regard to $\mathrm{pH}$, it is difficult to determine at which site the $\mathrm{pH}$ of the soil is the best-matched to suit the requirements of the plants.

With regard to the nutrient requirements of the vegetation, it can be said that most species prefer habitats that are either rich or only slightly deficient in resources, thus matching their actual habitat. However, although only one species (the blue fescue (Festuca ovina)) typical to poor habitats was recognized, it occurs in large numbers in four of the seven phytosociological listings.

Indicator Species: While examining the relationship between vegetation and habitat, one should take into account not only the most frequently occurring species, but also those that are less abundant, but have a narrow range of tolerance for ecological factors (the indicator species) - it is their presence that is the most indicative of the characteristics of the habitat and they are the species most strongly associated with the habitat. Using the indicator tables made by Zarzycki (1984) and the table by Jeż (1989), the indicator species for the existing habitat were chosen and the incidence of each of them was examined. Other species which have a narrow tolerance range for individual environmental factors, but were not included in the group of indicator species for the habitat studied, due to habitat characteristics, need to be analyzed separately, due to their great informational value with regards to the possible direction of plant community dynamics. Some of the indicator species found to be present in the study area were: the meadow foxtail (Alopecurus pratensis), lady's bedstraw (Galium verum), sainfoin (Onobrychis viciifolia), the solid-stem burnet saxifrage (Pimpinella saxifraga), smooth meadow-grass (Poa pratensis), the Canada goldenrod (Solidago 
The percentage of indicator species at each of the sites

\begin{tabular}{|c|c|l|}
\hline $\begin{array}{c}\text { Site } \\
\text { number }\end{array}$ & $\begin{array}{c}\text { \% of indicator species } \\
\text { in the listing }\end{array}$ & $\begin{array}{l}\text { Indicator species } \\
\text { (the names of species that are most numerous } \\
\text { at the given site are given in bold print) }\end{array}$ \\
\hline 1 & 25 & Taraxacum officinale, Vicia cracca \\
\hline 2 & 55 & $\begin{array}{l}\text { Pimpinella saxifraga, Poa pratensis, } \\
\text { Tanacetum vulgare, Taraxacum officinale, } \\
\text { Tragopogon pratensis }\end{array}$ \\
\hline 3 & 44 & $\begin{array}{l}\text { Poa pratensis, Solidago canadensis, } \\
\text { Taraxacum officinale, Tragopogon pratensis }\end{array}$ \\
\hline 4 & 33 & Galium verum, Onobrychis viciifolia \\
\hline 5 & 100 & Alopecurus pratensis \\
\hline 6 & 44 & $\begin{array}{l}\text { Galium verum, Tragopogon pratensis, } \\
\text { Verbascum phlomoides }\end{array}$ \\
\hline 7 & 25 & Galium verum, Solidago canadensis \\
\hline
\end{tabular}

canadensis), the common tansy (Tanacetum vulgare), the common dandelion (Taraxacum officinale), yellow goat's-beard (Tragopogon pratensis), the clasping mullein (Verbascum phlomoides), and the bird vetch (Vicia cracca).

It was found that in each site's listing of vascular plants there is at least one indicator species. In this case however, one should not consider the number of these species but their share in the overall number of species in the given listing. This is why the indicator species' share in the total number of species was calculated for each site, with the results presented in Table 2. The result obtained at site 5 (located the closest to the Vistula) is the highest, since only one species - the meadow foxtail (Alopecurus pratensis), which is at the same time an indicator species, is present there. In the vegetation listings no. 2 (by the road) and 3 (the farthest from the Vistula), the indicator species meadow foxtail (Alopecurus pratensis) and Canada goldenrod (Solidago canadensis), are also the most numerous species, at sites 2 and 3 respectively. One could assume that at these three sites, the vegetation is the most strongly linked to the habitat, since it reflects the state of the habitat and is present in large amounts. One does not notice the river or the morphology of the terrain having any effect upon the relation between the species composition and the habitat. (The sites described lie at various elevations of the terrain, e.g. site 3 is located in a depression and site 5 at an elevation.)

At all (seven) sites where the vascular plants were studied, grasses are present and at six of the sites, they are the most numerous species. In three phytosociological listings, the blue fescue (Festuca ovina) is the dominant species. As many as 11 of the species (half of all the species noted) are present at merely one or two sites. The most often-occurring species (present at the 
greatest number of sites) are: the common horsetail (Equisetum arvense) at 5 of the sites, the blue fescue (Festuca ovina) - at 4 of the sites, and the creeping thistle (Cirisium arvense) - at 4 of the sites.

Relations between tropic indicators in the soil and vegetation: The $\mathrm{W}_{x}$ concentration coefficients assembled in table 3 , being the ratio of the amount of the given element $x$ in a sample of vegetation mass to the amount of the same element in the soil (at the humus horizon), indicate the degree of the plant-dependence of individual elements. High plant-dependence (vegetation being the determiner) occurs whenever the concentration ratio of the humus horizon to the organic matter is low, and also whenever there is high contrast between the soil parent material and the humus horizon. This dependence model can be observed in the case of nitrogen. It is least apparent at the site at which the nitrogen content of the humus horizon is so low that the presence of the bird vetch (Vicia cracca) has led to the autonomization and high concentration of nitrogen in the plants. In contrast, the above model is most visibly being realized at site 3 , located in a depression, where despite the soil's nitrogen deficiency, there is successive accumulation of nitrogen at the humus horizon, and a lessening of the contrast between the amount of nitrogen content in the plant matter and in the humus horizon. Similar connections can be seen at site 2 . This is how the role of terrain microrelief (the existence of local elevations and depressions, with differences in altitude no greater than $1 \mathrm{~m}$, but significant due to the moisture characteristics of the underlying soil) becomes apparent. The depressions are caused by former outflow channels which currently often function as locations of prompt subsurface flow. On the other hand, the accumulation of sandy material in the form of local sand embankments leads to their autonomization and clear differentiation from this seemingly unvarying terrain.

Potassium and phosphorus, in that order, seem to be the less plant-dependent elements. Although their concentration in the vegetation is not as great as in the humus horizon, and even lower at times than analogous coefficients for nitrogen, the key link in the cycle is nevertheless the soil link (low coefficients). In the case being analyzed here, we are also dealing with a low level of potassium in the soil parent material (at sites 4,7 and 9 especially), what causes the low absorption of this element from the soil. In the case of phosphorus, when its content is uniformly low in the soil parent material, the low values of the concentration coefficients in the soil area indicate particularly strong autonomization, with regard to the effects of vegetation (especially at sites 8 and 1), what coupled with the high concentration coefficient of the vegetation area, indicates a deficiency of this element and its accumulation in the vegetation mass. On the other hand, a relatively high level of phosphorus content is present in the soil at sites 2 and 3 , and the relative bioconcentration in the plant matter observed there is not as great.

One may conclude that, due to the concentration coefficient values, the area described exhibits a rather low level of soil-plant linkage. The soil, which 
Table 3.

The concentration coefficient $\left(\mathrm{W}_{x}\right)$ with respect to the relations: 'vegetation - humus horizon' and 'humus horizon - soil parent material' $\left(\mathrm{W}_{\mathrm{N}}-\right.$ nitrogen, $\mathrm{W}_{\mathrm{P}}-$ phosphorus, $\mathrm{W}_{\mathrm{K}}$ - potassium, Org - organic material, Ah - humus horizon)

\begin{tabular}{|c|c|c|c|r|r|r|}
\hline \multirow{2}{*}{$\begin{array}{c}\text { Site } \\
\text { number }\end{array}$} & \multicolumn{2}{|c|}{$\mathrm{W}_{\mathrm{N}}$} & \multicolumn{2}{c|}{$\mathrm{W}_{\mathrm{P}}$} & \multicolumn{2}{c|}{$\mathrm{W}_{\mathrm{K}}$} \\
\cline { 2 - 7 } & $\mathrm{Org} / \mathrm{A}_{\mathrm{h}}$ & $\mathrm{A}_{\mathrm{h}} / \mathrm{C}$ & $\mathrm{O}$ Org/ $\mathrm{Ah}_{\mathrm{h}}$ & $\mathrm{A}_{\mathrm{h}} / \mathrm{C}$ & $\mathrm{Org} / \mathrm{A}_{\mathrm{h}}$ & $\mathrm{A}_{\mathrm{h}} / \mathrm{C}$ \\
\hline 1 & 13.4 & 13.9 & 2.7 & 7.9 & 4.0 & 8.2 \\
\hline 2 & 26.8 & 9.4 & 6.3 & 4.3 & 11.2 & 4.3 \\
\hline 3 & 51.5 & 5.9 & 6.5 & 3.7 & 1.3 & 30.7 \\
\hline 4 & 31.0 & 5.3 & 5.0 & 2.6 & 8.4 & 1.4 \\
\hline 5 & 30.6 & 8.9 & 4.8 & 4.7 & 11.5 & 6.3 \\
\hline 6 & 33.3 & 6.4 & 6.9 & 3.5 & 10.6 & 5.0 \\
\hline 7 & 20.5 & 5.0 & 5.2 & 2.6 & 5.3 & 3.5 \\
\hline 8 & 29.0 & 6.0 & 1.5 & 12.5 & 10.0 & 3.5 \\
\hline 9 & 10.5 & 5.1 & 3.9 & 3.0 & 4.9 & 2.6 \\
\hline 10 & 26.3 & 4.9 & 6.1 & 2.5 & 17.8 & 2.0 \\
\hline
\end{tabular}

usually serves as the factor determining the spread of vegetation, in this case merely serves as the scaffold for the roots of the plants. Soil and vegetation - the two most closely linked environmental components, seem to exhibit a low degree of interdependence in the area studied. This gives the impression of chaos and a lack of distinctly formed associations between the components, which is probably caused by the unusually dynamic character of the terrain (which may at any time undergo reconstruction - erosion of the river bank or the formation of new sandy embankments). In view of the above considerations, the conditions observed here should be treated as the documentation of a specific stage in the development of the Vistula river valley environment.

\section{CONCLUSIONS}

The study area is dominated by plants which are able to withstand intense sunlight and fluctuations in temperature. The plant composition exhibits a great diversity of species. Due to the type of soil parent material (sand) present in the study area, the plant dominating the area should be that, which prefers less fertile habitats, and yet due to the effects of the polluted water from the Vistula, acting to increase the fertility of the area, the observed state of the vegetation indicates, requirement-wise, a movement towards slightly more fertile habitats.

For most of the species found in the study area, the tolerance ranges for the $\mathrm{pH}$ and nutrient content of the habitat are quite wide. The plants that happen to have narrower tolerance ranges are found in more acidic sections of the terrain. Due to the fact that most species prefer habitats that are more 
acidic than the area studied, while the water in the Vistula has been shown to be alkaline, one could conclude that the soil is being enriched by water from the Vistula. High carbon content (site 6) may be correlated with the presence of the sand willow (Salix arenaria) on the plot studied; a tree which with its highly developed root system, compacts and binds the soil, while also attracting particles of dead vegetation blown in by the wind from elsewhere. This causes the amount of organic matter to be significantly greater at this site than at site 1 , despite the similar basic species composition.

The greater the share of vegetation not belonging to the grass family, the greater the carbon content. No association has been found between nitrogen content and the occurrence of plants from the Papilionaceae family. This is while the degree of humus transformation, expressed by the $\mathrm{C}: \mathrm{N}$ ratio, is low at sites where there are either few types of species or few types of nongrass species.

The shortage of water may be a factor lowering the trophism of the habitat and in effect result in poorer plant composition and lower trophism parameters, expressed by the nitrogen content. The availability of water is conditioned by the local microrelief.

The chaotic character of the environment analyzed indicates a lack of welldefined connections between the plant cover and the underlying soil, due to dynamic changes, caused by the Vistula, in the underlying soil itself. The spatial arrangement of soil trophism parameters, and of their relations within the soil and vegetation, is usually determined by the mineral substrate and by microrelief features. The reverse effect of the vegetation upon soil parameters is limited and essentially reduced to increasing the topsoil's nitrogen content.

\section{REFERENCES}

Duda J., Gumiński S., 1970, Fizjologia roślin [Plant Physiology; in Polish], PWN, Wrocław.

J e ż J., 1989, Ocena właściwości geotechnicznych podłoża gruntowego na podstawie szaty roślinnej [Assessment of geotechnical ground-soil properties based on vegetation cover; in Polish], Politechnika Poznańska - Rozprawy], No. 218, Poznań.

Ostrowska A., Gawliński S., Szczubiałka Z., 1991, Metody analizy i oceny właściwości gleb $i$ roślin: katalog [A catalogue of methods for the analysis and determination of soil and vegetation properties; in Polish], 1991, Instytut Kształtowania Środowiska Warszawa.

Podbielkowski Z, Podbielkowska M., 1992, Przystosowania roślin do środowiska [How Plants Adapt to the Environment; in Polish], WSiP, Warszawa.

R a h m a now O., 1999, Procesy zarastania Pustyni Btędowskiej [The Processes of Revegetation at the Błędowska Desert; in Polish], Wydział Nauk o Ziemi, Uniwersytet Ślaski, Sosnowiec.

Szweykowska A., Szw eykowski J., 1993, Botanika [Botany; in Polish], PWN, Warszawa. Tomaszewski J, 1969, Gleby takowe [Grassland soils; in Polish], PWRiL, Warszawa.

Zarzycki K., 1984, Ekologiczne liczby wskaźnikowe roślin naczyniowych Polski [Ecological Indicative Values for the Vascular Plants of Poland; in Polish], Instytut Botaniki PAN, Kraków. 